\title{
Public investment: catalyst for sustainable growth
}

ZDRAVKO MARIĆ, Ph.D.

Conference introductory note*

https://doi.org/10.3326/pse.42.2.5

\footnotetext{
* Received: December 20, 2017

Accepted: December 22, 2017
}

A conference introductory note given at the conference Public Sector Economics 2017 - Public investment: catalyst for sustainable growth organized by the Institute of Public Finance and Friedrich-Ebert-Stiftung in Zagreb on November 3, 2017.

\section{Zdravko MARIĆ}

Ministry of Finance of the Republic of Croatia, Katančićeva 5, 10000 Zagreb, Croatia e-mail: Zdravko.Maric@mfin.hr 
Investment ${ }^{1}$ is an important instrument of economic growth. Apart from having a positive effect on aggregate demand, it enables future production growth. Through capital accumulation, investments directly impact a country's potential GDP, i.e. the maximum sustainable level of output achievable by a country without creating inflationary pressure. Furthermore, new technologies can increase productivity and the utilization of factors of production.

Potential GDP growth rate in the EU declined by half after the onset of the 2008 crisis: in the 2002-2008 period, average potential GDP growth rate in the EU was $2 \%$, but dropped to $0.9 \%{ }^{2}$ in the $2009-2016$ period. This decline in growth is a consequence of, primarily, a significant reduction in total factor productivity and, secondarily, poor capital accumulation. The contribution of the labour factor has not been diminished to the same extent.

Croatia has experienced more unfavourable trends than other EU member states, with the pre-crisis potential GDP average growth rate exceeding $3 \%$, then declining or stagnating in the 2009-2014 period, and experiencing modest growth only in 2015. The primary factor contributing to post-crisis potential GDP growth slowdown was the capital factor, as its contribution in the post-crisis period was 2.5 times lower than when compared to the pre-crisis period, which was in line with investment trends in Croatia.

\section{GraPh 1}

Factors contributing to potential GDP growth

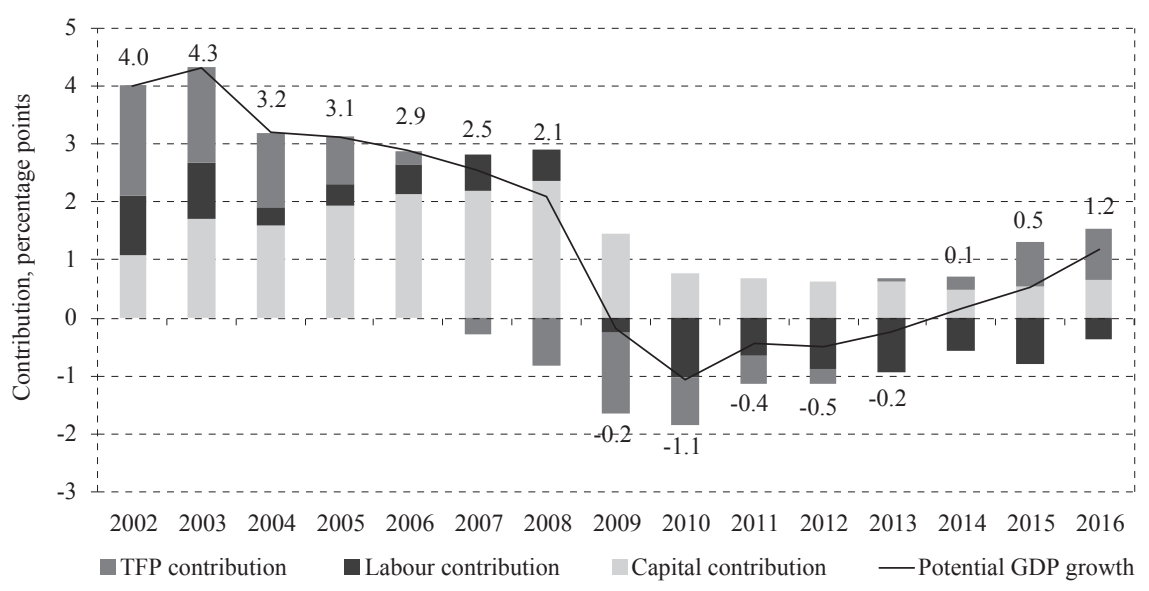

Source: Autumn Economic Forecast, European Commission, November 2017.

During the pre-crisis period, the growth of investments in Croatia was strong and was mostly financed by foreign capital and borrowing. A significant part of this growth was generated in the construction sector (primarily through investment into real property and infrastructure projects), while growth in other investment

\footnotetext{
${ }^{1}$ Investment here means gross fixed capital formation.

${ }^{2}$ Autumn Economic Forecast, European Commission, November 2017.
} 
categories was somewhat more modest. These trends led to a gradual increase in the investment rate, ${ }^{3}$ peaking in 2008 when it exceeded $28 \%$ of GDP. When compared with the EU average, investment rate in Croatia was significantly higher in the $2002-2008$ period (21.5\%, i.e. $25.8 \%$ of GDP, respectively). However, investment growth did not result in a strong productivity growth, for the most part because a significant portion of investments was going into nontradable sectors such as trade, financial mediation and construction.

At the onset of the crisis, foreign capital inflow was cut off and both the capital market and the property bubble burst, which led to a shrinkage of investment. In the 2009-2014 period, the investment rate in Croatia was gradually falling, to reach its lowest point at $19.3 \%$ of GDP in 2014. The year 2015 saw the beginning of a gradual recovery of investment, even though the share of investment in GDP remains much lower than before the crisis. For instance, the average investment rate in Croatia in the 2009-2016 period was only $20.6 \%$, which was somewhat higher than the average investment rate on EU level, but still lower than in new member states in the same period. One of the key changes when compared to the pre-crisis period is a change in investment structure, primarily in the form of an increase in investment into machinery, equipment and intellectual property, which resulted in an increased potential for productivity growth. Moreover, the higher percentage of investment pertains to the industry sector, while the share of investment in the construction sector has contracted significantly. When we look at investment structure by domestic sectors ${ }^{4}$, the majority of investments (approximately 60\%) are made in non-financial enterprises, followed by the general government sector (approximately 20\%) and the household sector (with an investment share of approximately $16 \%$ ), the remaining share relating to financial enterprises.

\section{GraPh 2}

Trends in gross fixed capital formation

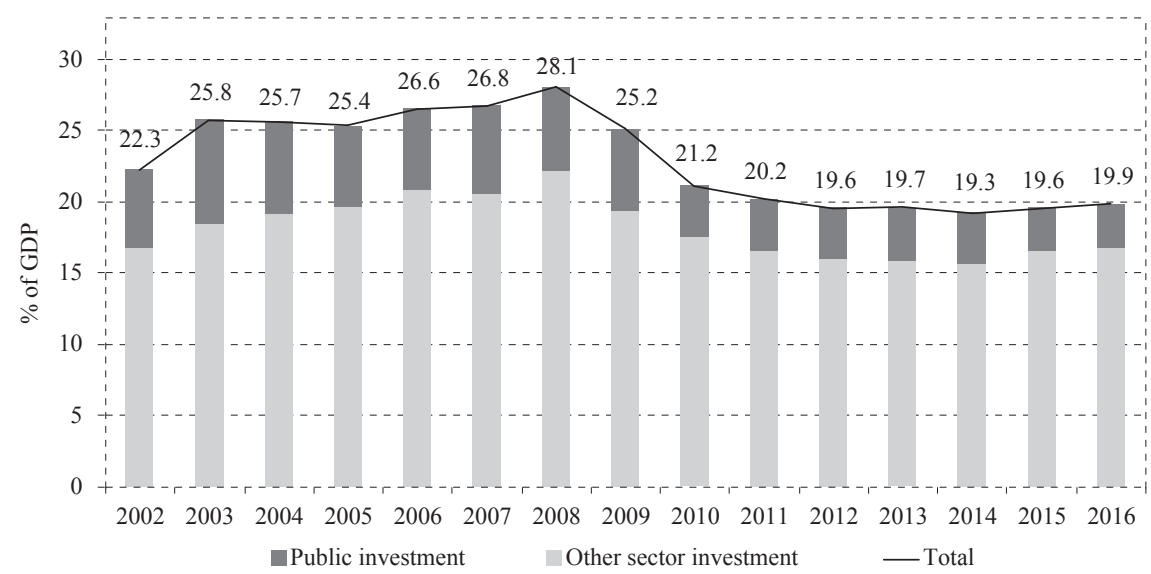

Note: Public investment means general government investment.

Source: Croatian Bureau of Statistics.

\footnotetext{
${ }^{3}$ Investment rate is defined as the share of gross fixed capital formation in GDP.

${ }^{4}$ Data is available for the 2002-2012 period. Source: Eurostat.
} 
The share of public investment in the 2002-2009 period was, on an average, $6.1 \%$ of GDP, dropping to $3.5 \%$ of GDP in 2010-2016. It peaked in 2008 at HRK 20.3bn and diminished continuously since, resulting in HRK $10.3 \mathrm{bn}$, i.e. HRK $10.7 \mathrm{bn}$ in 2015 and 2016, respectively. In other words, the impact of the recession on the drop in investment activities was significant, resulting in the current low level of investment.

Such public investment trends were brought about by the necessity of fiscal consolidation and limiting public debt growth. After 2008, when public deficit was at $2.8 \%$ of GDP, it started showing an upward trend, resulting in an average $6 \%$ of GDP in the 2009-2014 period. At the same time, public debt more than doubled, rising from a stable $40 \%$ of GDP average in the $2002-2008$ period to a high $85.8 \%$ of GDP in 2014. These fiscal trends were a direct consequence of a deep recession and restructuring that affected the Croatian economy, not sparing some stateowned public enterprises that had been the engine of investment activity in the pre-crisis period.

\section{GraPh 3}

General government deficit and debt

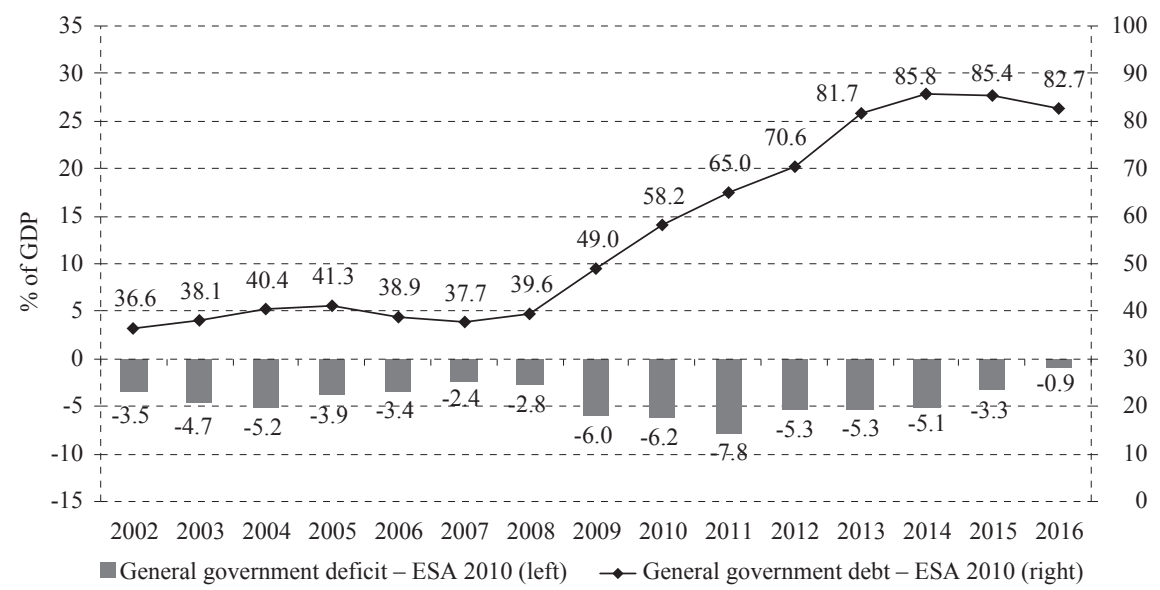

Source: Ministry of Finance, Croatian Bureau of Statistics.

In this context, in January 2014, the Council of the European Union decided to launch an excessive deficit procedure in order to reduce deficit to below 3\% of GDP by the end of 2016 and to have general government debt on a sustainable trajectory to below $60 \%$ of GDP. In March 2016, the European Commission concluded that Croatia was experiencing excessive macroeconomic imbalances. In order to meet the Recommendations, fiscal consolidation measures were implemented, which affected most public spending categories, including public investments. Due to high interest rates on the financial markets and limited fiscal options, only necessary investment projects, mostly those dealing with transport and water infrastructure, were greenlighted. 
Due to fiscal consolidation and good performance in 2016, Croatia exited the excessive deficit procedure in June 2017. In the course of 2016, the budget deficit dropped to $0.9 \%$ of GDP and public debt dropped to $82.7 \%$ of GDP, allowing Croatia to rank among EU member states with a most significant annual public debt-to-GDP ratio improvement. 2017 fiscal results exceeded expectations, meaning that budget deficit will fall below $0.6 \%$ of GDP. Croatia will have to continue fiscal consolidation in the years to come to ensure that deficit and public debt trends remain in accordance with Stability and Growth Pact provisions.

Public investment will therefore continue to depend on the obligation to pursue a prudent fiscal policy. As a consequence thereof, the Government will focus on EU funds absorption. According to the new Act on the Financing of Units of Local and Regional Self-government, effective as of January $1^{\text {st }}, 2018$, personal income tax will fall under the authority of local units in order to top up their budgets and with the aim to increase investment and better absorb EU funds. Moreover, enterprises majority-owned by the state outside of the general government sector, whose investments, according to Ministry of Finance estimate, account for 6-7\% of total investment, play an important role in the increase in investment activity. These are primarily enterprises of strategic interest pertaining to the energy and transport sectors. It is, however, imperative to choose investment projects with highest return on invested capital and which serve the needs of real economy. It would be ideal, therefore, to use EU funds as much as possible for investment financing, particularly in the context of the Investment Plan for Europe (the so-called "Juncker Plan"), which was initiated precisely because of low levels of investment in the EU in comparison with the pre-crisis period.

When it comes to the private sector, significant investments have been made in the tourism sector and an upward trend is clearly visible in the industry sector. However, in spite of much better financing conditions, private sector investment remains hampered by high indebtedness and the need for further deleveraging. Namely, private sector (nonfinancial enterprises and households) debt share at the end of 2016 amounted to $105.9 \%$ of GDP, the share of nonfinancial enterprises being $70.6 \%$ of GDP. Even though the debt has been reduced when compared with 2010, when it reached its maximum, this amount of debt limits the private sector's options for new investment and makes it vulnerable to changes in financing conditions. Moreover, the banking sector is still burdened with high level of non-performing loans: at the end of September of 2017, 12.5\% of total bank loans were irrecoverable or only partially recoverable ${ }^{5}$. The vast majority of nonperforming loans are found in the non-financial enterprise sector ( $25.9 \%$ of total loans), especially in construction, which is probably due to the sharp rise of the construction sector during the pre-crisis period. In 2017, the Government introduced a one-off opportunity to have nonperforming loans, valued as of $31^{\text {st }}$ December 2015, considered as tax expenditure as part of a comprehensive tax system reform and

\footnotetext{
${ }^{5}$ The share of such loans in total loans reached its maximum in $2014-17.1 \%$.
} 
pursuant to 2016 Council recommendations, with a view to reduce private sector debt. This move enabled banks to reduce tax liabilities on corporate income tax for the amount of written-off debt.

Another goal of the lowering of the tax burden as part of the tax system reform was to reduce direct personal income and corporate income taxation and in this way encourage personal consumption and investment. The tax burden on all corporate income taxpayers was thus reduced, offering a dedicated incentive to the development of small enterprises and start-ups by reducing the tax rate from $20 \%$ to $18 \%$, or to $12 \%$ for taxpayers whose annual income does not exceed HRK $3 \mathrm{~m}$. In order to enhance tax certainty and remove obstacles for the expansion of foreign and domestic investment, the possibility has been introduced to enter into an advance transfer pricing agreement. Reliefs for assisted regions (PP1 and the city of Vukovar), education, research and development, and reliefs under the Investment Promotion Act remain available. New amendments to the Investment Promotion Act have been presented for debate before Parliament, aimed at enabling small and micro-enterprises and the ICT industry to use incentives in order to increase project realization rates and offering the option to make free of charge use of unused government property for ten years.

The tax burden will be further lowered in 2018. On January $1^{\text {st }}$, measures to increase enterprise liquidity will come into effect. These include the application of the accrual principle (without tax prepayment) on investment equipment imports from third countries and the right to a 50\% input VAT deduction for personal vehicles used for business purposes, as well as a rise in the VAT registration threshold from HRK 230,000 to HRK 300,000 to exclude small taxpayers. A further reduction of non-tax payments is also planned in order to reduce enterprise costs by removing obstacles to doing business in particular sectors, and creating a simpler and more efficient regulatory framework.

When it comes to financing conditions, favourable trends will continue and lead to an increase in investment in both the public and the private sector. In the last year, the three leading rating agencies boosted Croatia's credit rating. CDS (credit default swap) spread on five-year bonds has fallen to its lowest level since 2008. All in all, long-term reduction of borrowing costs, lower country risk premiums and a boosted credit rating will allow greater capital availability and lower capital costs for both the public and private sector. 